\title{
Prenatal echocardiographic diagnosis of cardiac right/left axis and malpositions according to standardized Cordes technique
}

\author{
Standart Cordes tekniğine göre kalbin sağ/sol ekseninin ve malpozisyonlarının \\ prenatal ekokardiyografik tanısı
}

Süheyla Özkutlu, Özlem Mehtap Bostan1, Özgür Deren*, Lütfï Önderoğlu*, Gülsev Kale**, Şafak Güçer**, Diclehan Orhan**

From Departments of Pediatric Cardiology, ${ }^{*}$ Obstetrics and Gynecology and ${ }^{* *}$ Pediatric Pathology, Faculty of Medicine, Hacettepe University, Ankara, ${ }^{1}$ Department of Pediatric Cardiology, Faculty of Medicine, Uludağ University, Bursa, Turkey

\section{ABSTRACT}

Objective: The aim of this study was to evaluate distinguishing the right / left side of the fetus, cardiac axis and position according to the standardized Cordes technique in 20 cases with cardiac malposition.

Methods: We studied retrospectively 1536 cases whose fetal echocardiographic examinations were performed between 1999 and 2006 in prenatal cardiology unit. Among these, cardiac malpositions were determined in 20 cases. The cardiac axis and position were determined according to the Cordes technique. All cases were followed-up by serial fetal echocardiograms until birth or intrauterine death occurred. In cases of intrauterine death, an autopsy was performed. After birth, physical and echocardiographic examinations were done and prenatal and postnatal diagnoses were compared.

Results: Of 1536 fetal echocardiograms performed, 144 revealed congenital heart diseases $(9.4 \%)$, among these cases 20 were diagnosed with cardiac malposition. Of cases with cardiac malposition, 16 had congenital heart disease, and four had extracardiac malformation. There were six cases of isolated dextrocardia, three cases of situs inversus totalis, six cases of situs ambiguous, and one case of situs inversus with isolated levocardia. Of four cases with extracardiac malformations, two cases had mesoposition, one had dextroposition, and one had extreme levoposition. In six cases the autopsy findings were the same as that their prenatal echocardiographic findings. When postnatal echocardiographic results of the remaining cases with cardiac malposition due to congenital heart disease were compared with prenatal diagnoses, the same echocardiographic findings were verified.

Conclusion: The fetal right/left axis must be determined correctly for the accurate diagnosis of cardiac malpositions. Therefore, we recommend that Cordes technique provides a simple and reliable determination of the fetal right/left axis and fetal situs.

(Anadolu Kardiyol Derg 2011; 2: 131-6)

Key words: Fetal echocardiography, fetal situs, fetal cardiac malposition, dextrocardia, situs ambiguous, Cordes technique

ÖZET

Amaç: Bu çalışmada, standart Cordes tekniğine göre fetüsün sağ/sol tarafının, kalbin aksının ve pozisyonunun ayrımı ve bu teknikle kardiyak malpozisyon tanısı konulan 20 olgunun değerlendirilmesi amaçlandı.

Yöntemler: Çalışmamızda, 1999-2006 yılları arasında prenatal Kardiyoloji ünitesinde fetal ekokardiyografi yapılan 1536 olguyu retrospektif olarak değerlendirildi. Bu olguların 20'sinde kardiyak malpozisyon saptandı. Kalbin aksı ve pozisyonu Cordes tekniğe göre saptandı. Tüm olgular seri fetal ekokardiyografik çalışmalar ile doğuma veya intrauterinde ölüm meydana gelene kadar izlendi. Intrauterin ölen olgulara otopsi yapıldı. Doğumdan sonra fizik muayene ve ekokardiyografik değerlendirme yapıldı, prenatal ve postnatal tanılar karşılaştıııldı.

Bulgular: Fetal ekokardiyografi yapılan 1536 olgunun 144' ünde konjenital kalp hastalığı saptandı ve bu olguların 20'sine kardiyak malpozisyon tanısı konuldu. Kardiyak malpozisyonlu olguların 16'sında konjenital kalp hastalığı ve 4'ünde kalp dışı nedenlere bağlı malpozisyon mevcuttu. Altı olguda izole dekstrokardi, 3 olguda situs inversus totalis, 6 olguda situs ambigus ve 1 olguda izole levokardi ile birlikte situs inversus saptand.

Address for Correspondence/Yazışma Adresi: Dr. Süheyla Özkutlu, Department of Pediatric Cardiology, Faculty of Medicine, Hacettepe University, Ankara, Turkey Phone: +90 31230511 57-58 Fax: +90 3123090220 E-mail: suheylaozkutlu@yahoo.com

This work was presented at the Second Annual Congress on Update in Cardiology and Cardiovascular Surgery, 20-24 September 2006, Bodrum/Turkey

Accepted Date/Kabul Tarihi: 01.09.2010 Available Online Date/Çevrimiçi Yayın Tarihi: 08.02.2011

(C)Telif Hakkı 2011 AVES Yayıncılık Ltd. Şti. - Makale metnine www.anakarder.com web sayfasından ulaşılabilir.

(C) Copyright 2011 by AVES Yayıncillk Ltd. - Available on-line at www.anakarder.com doi:10.5152/akd.2011.033 
Kalp dışı nedenlere bağlı malpozisyonlu 4 olgunun 2'sinde mezopozisyon, 1'inde dekstropozisyon ve 1'inde ileri levopozisyon mevcuttu. Altı olguya yapılan otopsi bulguları prenatal ekokardiyografik bulgular ile benzerdi. Konjenital kalp hastalığına bağlı kardiyak malpozisyonlu diğer olguların doğum sonrası ekokardiyografik sonuçları prenatal tanılarıyla karşılaştırıldığında aynı sonuçlar elde edildi.

Sonuç: Kardiyak malpozisyonun doğru tanısı için fetüsün sağ/sol aksı doğru saptanmalıdır. Bu nedenle fetal situs ve fetüsün sağ/sol aksının saptanmasında kolay ve güvenilir bir teknik olan Cordes tekniğini öneriyoruz. (Anadolu Kardiyol Derg 2011; 2: 131-6)

Anahtar kelimeler: Fetal ekokardiyografi, fetal situs, fetal kardiyak malpozisyon, dekstrokardi, situs ambigus, Cordes tekniği

\section{Introduction}

Fetal cardiac malpositions are difficult to diagnose in routine screening ultrasound. Determining the fetal right/left axis is essential for the diagnosis. Constantly variable fetal position within the uterus can confuse distinguishing the right/left side of the fetus. Variability among echocardiographers regarding image acquisition adds to this confusion. If there is confusion regarding the right/left axis, then atrial and visceral situs, cardiac position and cardiac segmental anatomy cannot be evaluated correctly. There are some recommended techniques and images required for a standard fetal echocardiogram (1-6).

In this study, the 20 cases among 1536 cases diagnosed as cardiac malposition using standardized technique recommended by Cordes et al. (2) for assignment of fetal right / left axis were evaluated. The accuracy of prenatal diagnosis was compared with postnatal echocardiographic diagnosis and autopsy findings.

\section{Methods}

\section{Study patients}

We studied retrospectively 1536 cases whose fetal echocardiographic examinations were performed between 1999 and 2006 in prenatal cardiology unit. Among these, cardiac malposition was determined in 20 cases and these cases performed our study group. These cases were referred to our center either from the departments of obstetrics and gynecology of our institution or from other centers by obstetricians or by pediatric cardiologist. Some were siblings of our patients with congenital heart defects and fetuses of mothers with congenital heart defects. Data of 20 cases with cardiac malposition were evaluated in respect to gestational week, maternal age, maternal and familial medical histories, previous obstetric history, fetal and postnatal echocardiographic examinations, and autopsy findings.

\section{Fetal echocardiography}

The prenatal and postnatal echocardiographic examinations were performed using a Trinitron GE Vivid Five performance echocardiographic scanner with 2.5-5 $\mathrm{MHz}$ transducers (Cardiovascular Ultrasound Systems, General Electric, Horten, Norway). All echocardiographic examinations were performed by the same pediatric cardiologist and all studies were recorded on videotape. The fetal examination included the standard positions used in fetal heart scanning technique (7). The cardiac axis and position were determined according to the technique described by Cordes et al. (2).

\section{Cordes technique}

In this technique the fetal head and sagittal plane of fetal body are then located. The transducer is oriented so that it is parallel to the fetal sagittal plane, with the fetal head on the right side of the video screen. When the transducer is aligned parallel to the fetal cranial-caudal axis this way, the side of the transducer toward the fetal head can be designated the "top" of the transducer. The transducer is then rotated clockwise (from the perspective of the echocardiographer) 90 degrees, to visualize optimally a transverse image of the fetal thorax. In this transverse image, the fetus' left side is on the right of the video screen, and the fetus' right side is on the left of the video screen (Fig. 1) (2).

A systematic approach was used based on segmental anatomy $(8,9)$. Viscero-atrial situs was determined as situs solitus, inversus, or ambiguous. In this study, the type of cardiac malposition was determined by the cardiac base-apex axis as dextrocardia, mesocardia and levocardia.

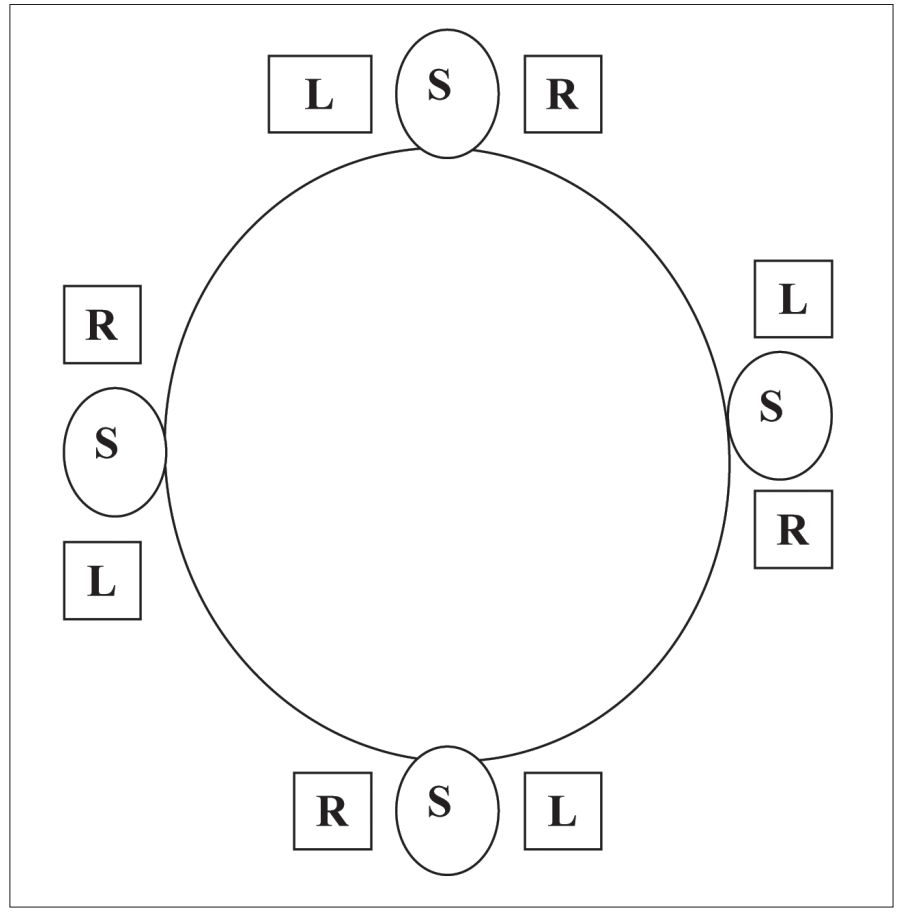

Figure 1. Schematic drawing of fetal trunk as viewed in transverse plane on video display

With fetal spine used as landmark, right and left sides of fetus can be determined Relationship of right and left sides of fetus and spine are constant despite fetal rotation from face up (bottom), right side up (left), face down (top), and left side up (right) S - spine, L - left, R - right (modified from Cordes TM, O'Leary PW, Seward BS, Hagler DJ. Distinguishing right from left: A standardized technique for fetal echocardiography. J Am Soc Echocardiogr 1994; 7:47-53) 
Situs solitus was defined as liver on the right side and the stomach on the left side, with the right inferior caval vein and the superior caval vein connecting to the systemic right atrium on the right side. Situs inversus was defined as a mirror-image configuration so that the liver was on the left side and the stomach was on the right, with the left inferior caval vein and superior connecting to the systemic right atrium on the left. Situs ambiguous was defined as the liver on the midline position and indeterminate stomach situs, abnormal inferior caval vein connection, or relations with the descending aorta. Situs ambiguous was divided into two major subtypes: left atrial isomerism and right atrial isomerism. These were categorized based on the following echocardiographic criteria: a diagnosis of left atrial isomerism was made if there was an interrupted inferior caval vein with azygous continuation and anterior located descending aorta according to azygous vein, and a diagnosis of right atrial isomerism was made if the inferior caval vein and aorta was both located on the right or left side of the spine in parallel anteroposterior orientation $(8,9)$.

In this study, dextrocardia was defined as the location of the heart in the right hemithorax with the apex pointing to the right. Dextrocardia was divided into two subgroups: Isolated dextrocardia and situs inversus. Dextrocardia was defined as isolated dextrocardia, occurring in conjunction with situs solitus and situs ambiguous. Mesocardia was defined as location of the heart with the cardiac base-apex axis directed to the midline of the thorax or with ventricular apices equally directed to both right and left sides. Levocardia was defined as the location of the heart in the left hemithorax with the apex pointing to the left. Levocardia as a cardiac malposition was also defined as isolated levocardia, occurring in conjunction with situs inversus and situs ambiguous (8). In this study, the pathologic displacement of the heart into the right or left thorax by extracardiac malformations was defined as dextroposition, mesoposition and levoposition (8).

All cases were followed-up by serial fetal echocardiograms until birth or intrauterine death occurred. In cases of intrauterine death, an autopsy was performed. After birth, physical and echocardiographic examinations were done and prenatal and postnatal diagnoses were compared.

\section{Statistical analysis}

All statistical analyses were performed using the SPSS 15.0 statistical software (Chicago, IL, USA). Quantitative variables are expressed as mean \pm standard deviation, and qualitative variables are given as frequency and percentage. Reliability of fetal echocardiography for diagnose of cardiac malpositions was evaluated by sensitivity and specificity formulas.

\section{Results}

Of 1536 fetal echocardiograms performed, 144 revealed congenital heart diseases $(9.4 \%)$, among these cases, 20 were diagnosed with cardiac malposition. Of these cases, 16 had congenital heart disease, and 4 had extracardiac malformation (Table 1). All the other cases (124 cases) had situs solitus, levocardia and left cardiac axis between $60^{\circ}$ and $90^{\circ}$. The mean gestational age and the maternal age at the time of first examination was $28 \pm 5$ weeks (range $20-37$ weeks) and $30.0 \pm 3.6$ years (range 24-35 years), respectively.

The indications for referral for fetal echocardiographic examination were suspected congenital heart disease, fetal arrhythmia, and fetal hydrops on routine obstetric ultrasound. Seven of 20 cases were referred for fetal echocardiography after a preliminary diagnosis of cardiac malposition. One case, referred for fetal echocardiography after a preliminary diagnosis of dextrocardia on obstetric ultrasound and magnetic resonance imaging examination, had normal cardiac anatomy and position. Except the cases 10 and 18, maternal and familial medical histories, and previous obstetric history of all cases were unremarkable. Case 10 had a sibling with situs inversus totalis and transposition of the great arteries, and the mother of the case 18 had congenital heart disease.

Of 20 cases with cardiac malposition, 16 cases had congenital heart disease, four cases had extracardiac malformation. There were six cases of isolated dextrocardia, three cases of situs inversus totalis, and six cases of situs ambiguous, and one case of situs inversus with levocardia (Fig. 2A-B) (Table 1). Of six cases with situs ambiguous, five cases had left atrial isomerism and levocardia (Fig. $3 \mathrm{~A}-\mathrm{B}$ ) and one case had right atrial isomerism and dextrocardia (Fig. 4). Of four cases with cardiac malposition caused by extracardiac congenital malformation, two cases had mesoposition due to pleural effusion, one case had dextroposition due to left-sided congenital diaphragmatic hernia, and one case had an extreme levoposition due to cystic adenomatoid malformation in the right lung (Table 1). All of them had normal cardiac anatomy.

In follow-up, in six cases (case 10,11, 13, 14, 16, and 19) pregnancy was terminated (Table 1). The autopsy findings of these cases were the same as their prenatal echocardiographic findings. The remaining cases were born and have survived the neonatal period.

On postnatal echocardiographic examination these cases had the same echocardiographic findings with prenatal diagnosis. There were not false negative and false positive results in the cases with cardiac malposition, in terms of fetal echocardiographic diagnosis. The sensitivity of the prenatal echocardiographic examination in diagnosing cardiac malpositions was calculated as $100 \%$ and specificity was $100 \%$.

\section{Discussion}

Recently, advances in ultrasound technology and increased experience in fetal echocardiography have led to increased sensitivity and specificity of fetal echocardiography in the accuracy of diagnose of congenital heart disease (10-12). However, the prenatal diagnosis of cardiac malpositions is difficult. 

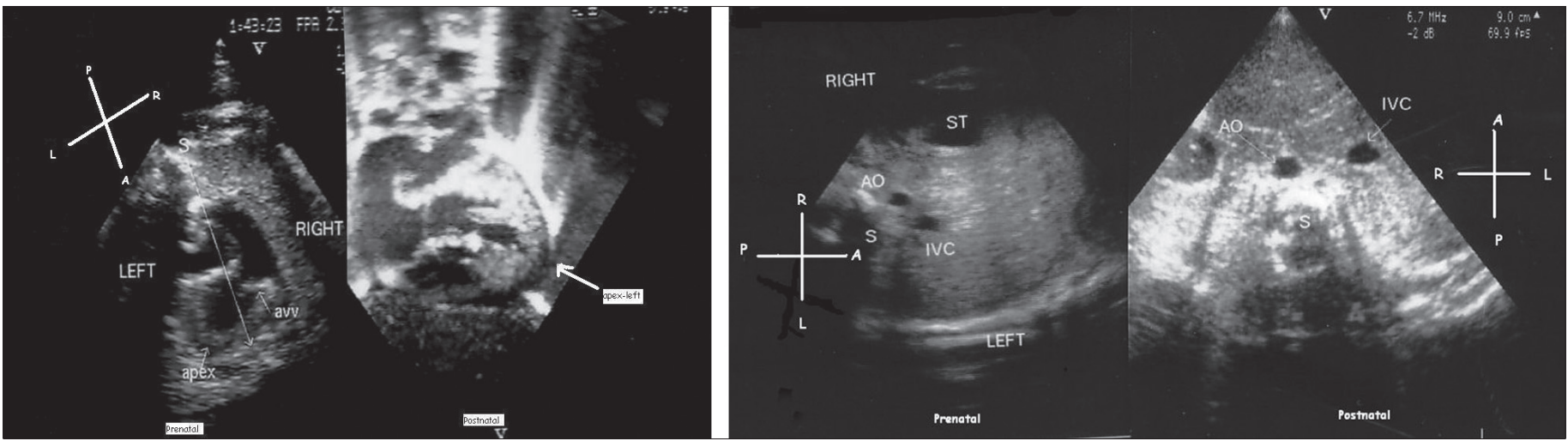

Figure 2. Prenatal and postnatal echocardiographic images demonstrating isolated levocardia in the fetus with complex cardiac anomaly. A: With fetal spine used as landmark, the apex of the heart is directed toward the left side of the fetal chest (schematic drawing left side up) B: The fetal stomach and the aorta are positioned in the right side (schematic drawing left side down)

AVV - atrioventricular valve, S - spine, Ao - Aorta, IVC - inferior vena cava, ST - stomach, A - anterior, P - posterior, L - left, R - right

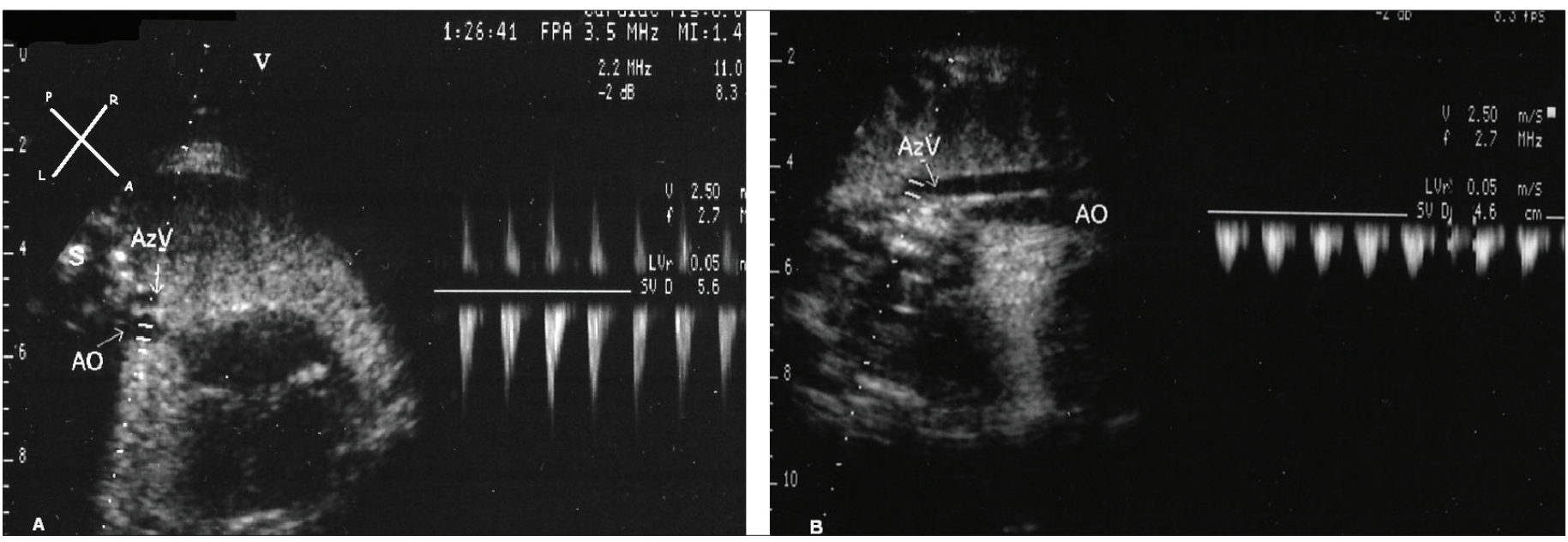

Figure 3. Four-chamber view in the fetus with left atrial isomerism. A: Two vessels are seen in front of the spine, the larger, more anterior vessel is the descending aorta, the smaller one the azygous continuation of the inferior vena cava (schematic drawing left side down) B: Two vessels are seen in the posterior thorax, the more posterior proved to be the azygous continuation of the inferior vena cava

$S$ - spine, Ao - aorta, AzV - azygous vein, A - anterior, P - posterior, L - left, R - right

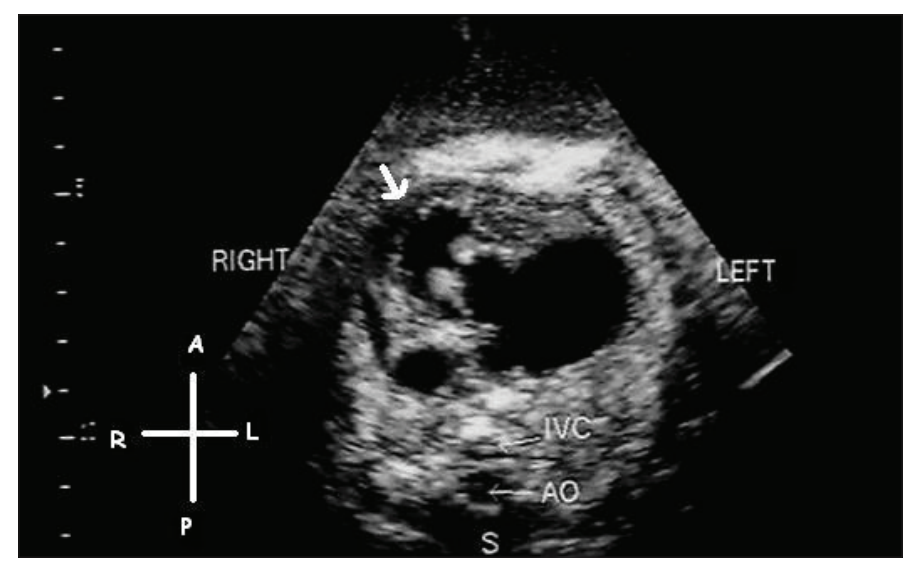

Figure 4. Dextrocardia and right atrial isomerism in the fetus with common inlet right ventricle. With fetal spine used as landmark, the apex (arrow) of the heart is directed toward the right side of the fetal chest and the abdominal vessels showing the aorta and inferior vena cava lying antero-posteriorly to each other and directly in front of the spine (schematic drawing left side down and right side down)

$S$ - spine, Ao - aorta, IVC - inferior vena cava, A - anterior, P - posterior, L - left, R - right
Therefore, cardiac malpositions are usually diagnosed by postnatal echocardiographic examination or autopsy. The current methods to distinguish the right side of the fetus from the left side on the transabdominal ultrasound examination rely on several parameters including maternal position, fetal position and transducer orientation. In present study, visceroatrial situs, cardiac position and cardiac segmental anatomy were evaluated according to the technique described by Cordes et al. (2). Since 1998, in our prenatal cardiology unit this technique has been preferred because it is easily applied, and it reduces confusion significantly relating to fetal right/left axis. This study using Cordes technique showed that there was no difference between the type of cardiac malposition diagnosed prenatally and postnatally (sensitivity and specificity 100\%).

There are a few published studies about malpositions (13-16). Walmsley et al. (16) retrospectively reviewed the fetal echocardiographic diagnosis of dextrocardia in large series. In this study, 85 cases of dextrocardia were diagnosed from 5539 fetal echocardiograms and thirty-three of these cases had been referred for fetal 
Table 1. Diagnoses and features of the cases with cardiac malposition

\begin{tabular}{|c|c|c|c|c|c|c|c|}
\hline Cases & $\begin{array}{l}\text { Gestational age } \\
\text { at presentation, } \\
\text { weeks }\end{array}$ & $\begin{array}{l}\text { Visceroatrial } \\
\text { situs }\end{array}$ & $\begin{array}{c}\text { Cardiac apex } \\
\text { orientation }\end{array}$ & $\begin{array}{l}\text { Cardiac } \\
\text { Axis }\end{array}$ & $\begin{array}{l}\text { Congenital } \\
\text { heart disease }\end{array}$ & $\begin{array}{l}\text { Extracardiac } \\
\text { anomalies }\end{array}$ & Outcome \\
\hline Case 1 & 27 & $\begin{array}{c}\text { Ambiguous } \\
\text { (left atrial isomerism) }\end{array}$ & $\begin{array}{l}\text { Isolated } \\
\text { Levocardia }\end{array}$ & $\begin{array}{l}\text { Left axis } \\
77^{\circ}\end{array}$ & $\begin{array}{c}\text { AVSD } \\
\text { DORV } \\
\text { PS } \\
\text { hemiazygous vein continuation }\end{array}$ & - & $\begin{array}{c}\text { Alive, } \\
\text { Following-up }\end{array}$ \\
\hline Case 2 & 30 & $\begin{array}{c}\text { Ambiguous } \\
\text { (left atrial isomerism) }\end{array}$ & $\begin{array}{l}\text { Isolated } \\
\text { Levocardia }\end{array}$ & $\begin{array}{l}\text { Left axis } \\
75^{\circ}\end{array}$ & $\begin{array}{c}\text { AVSD } \\
\text { azygous vein continuation }\end{array}$ & $\begin{array}{l}- \\
-\end{array}$ & $\begin{array}{c}\text { Alive, } \\
\text { Following-up }\end{array}$ \\
\hline Case 3 & 32 & $\begin{array}{c}\text { Ambiguous } \\
\text { (left atrial isomerism) }\end{array}$ & $\begin{array}{l}\text { Isolated } \\
\text { Levocardia }\end{array}$ & $\begin{array}{l}\text { Left axis } \\
65^{\circ}\end{array}$ & $\begin{array}{c}\text { Sup.Inf. } \\
\text { Ventricle } \\
\text { VSD+ASD } \\
\text { Ventriculo-arterial discordance } \\
\text { azygous vein continuation }\end{array}$ & & $\begin{array}{c}\text { Alive, } \\
\text { Following-up }\end{array}$ \\
\hline Case 4 & 28 & $\begin{array}{c}\text { Ambiguous } \\
\text { (left atrial isomerism) }\end{array}$ & $\begin{array}{l}\text { Isolated } \\
\text { Levocardia }\end{array}$ & $\begin{array}{l}\text { Left axis } \\
70^{\circ}\end{array}$ & $\begin{array}{c}\text { DORV } \\
\text { Subpulmonic } \\
\text { VSD } \\
\text { PS } \\
\text { hemiazygous vein continuation }\end{array}$ & - & $\begin{array}{c}\text { Alive, } \\
\text { Following-up }\end{array}$ \\
\hline Case 5 & 30 & Inversus & $\begin{array}{l}\text { Isolated } \\
\text { Levocardia }\end{array}$ & $\begin{array}{l}\text { Left axis } \\
80^{\circ}\end{array}$ & $\begin{array}{l}\text { DIRV } \\
\text { Pulmonary atresia } \\
\text { ASD } \\
\text { MAPCA }\end{array}$ & - & $\begin{array}{c}\text { Alive, } \\
\text { Following-up }\end{array}$ \\
\hline Case 6 & 37 & $\begin{array}{c}\text { Ambiguous } \\
\text { (right atrial isomerism) }\end{array}$ & Dextrocardia & $\begin{array}{l}\text { Right axis } \\
75^{\circ}\end{array}$ & $\begin{array}{c}\text { Common inlet right ventricle } \\
\text { Large primum and secundum ASD } \\
\text { (common atrium), MGA+Hypoplastic } \\
\text { pulmonary artery }\end{array}$ & - & $\begin{array}{l}\text { Intrauterine } \\
\text { fetal death } \\
\text { and autopsy } \\
\text { was performed }\end{array}$ \\
\hline Case 7 & 34 & Solitus & \begin{tabular}{|c|} 
Isolated \\
Dextrocardia
\end{tabular} & $\begin{array}{l}\text { Right axis } \\
60^{\circ}\end{array}$ & $\begin{array}{l}\text { DORV } \\
\text { VSD }\end{array}$ & - & $\begin{array}{c}\text { Alive, } \\
\text { Following-up }\end{array}$ \\
\hline Case 8 & 23 & Solitus & $\begin{array}{c}\text { Isolated } \\
\text { Dextrocardia }\end{array}$ & $\begin{array}{l}\text { Right axis } \\
60^{\circ}\end{array}$ & $\begin{array}{c}\text { Primum ASD } \\
\text { Common inlet single ventricle } \\
\text { MGA }\end{array}$ & - & $\begin{array}{c}\text { Alive, } \\
\text { Following-up }\end{array}$ \\
\hline Case 9 & 21 & $\begin{array}{c}\text { Ambiguous } \\
\text { (left atrial isomerism) }\end{array}$ & $\begin{array}{l}\text { Isolated } \\
\text { Levocardia }\end{array}$ & $\begin{array}{l}\text { Left axis } \\
72^{\circ}\end{array}$ & $\begin{array}{c}\text { VSD } \\
\text { Sinus venosus ASD } \\
\text { azygous vein continuation }\end{array}$ & - & $\begin{array}{c}\text { Alive, } \\
\text { Following-up }\end{array}$ \\
\hline Case 10 & 24 & Inversus & Dextrocardia & $\begin{array}{c}\text { Right axis } \\
68^{\circ}\end{array}$ & $\begin{array}{l}\text { TGA } \\
\text { VSD }\end{array}$ & - & $\begin{array}{l}\text { Pregnancy } \\
\text { termination } \\
\text { and autopsy }\end{array}$ \\
\hline Case 11 & 24 & Solitus & $\begin{array}{c}\text { Isolated } \\
\text { Dextrocardia }\end{array}$ & $\begin{array}{l}\text { Right axis } \\
60^{\circ}\end{array}$ & $\begin{array}{l}\text { Common inlet single ventricle } \\
\text { Common atrium }\end{array}$ & - & $\begin{array}{l}\text { Pregnancy } \\
\text { termination } \\
\text { and autopsy }\end{array}$ \\
\hline Case 12 & 34 & Inversus & Dextrocardia & $\begin{array}{l}\text { Right axis } \\
70^{\circ}\end{array}$ & VSD & - & $\begin{array}{c}\text { Alive, } \\
\text { Following-up }\end{array}$ \\
\hline Case 13 & 19 & Solitus & $\begin{array}{c}\text { Isolated } \\
\text { Dextrocardia }\end{array}$ & $\begin{array}{l}\text { Right axis } \\
60^{\circ}\end{array}$ & $\begin{array}{c}\text { Primum ASD } \\
\text { Dimunitive RV+Inlet VSD } \\
\text { (small)+INCVM+PA }\end{array}$ & - & $\begin{array}{l}\text { Pregnancy } \\
\text { termination } \\
\text { and autopsy }\end{array}$ \\
\hline Case 14 & 18 & Solitus & $\begin{array}{c}\text { Isolated } \\
\text { Dextrocardia }\end{array}$ & $\begin{array}{l}\text { Right axis } \\
60^{\circ}\end{array}$ & Outlet VSD & Gastroschisis & $\begin{array}{l}\text { Pregnancy } \\
\text { termination } \\
\text { and autopsy }\end{array}$ \\
\hline Case 15 & 37 & Inversus & Dextrocardia & $\begin{array}{c}\text { Right axis } \\
58^{\circ}\end{array}$ & $\begin{array}{c}\text { Primum ASD } \\
\text { Common ventricle }\end{array}$ & - & $\begin{array}{c}\text { Alive, } \\
\text { Following-up }\end{array}$ \\
\hline Case 16 & 24 & Solitus & $\begin{array}{c}\text { Isolated } \\
\text { Dextrocardia }\end{array}$ & $\begin{array}{l}\text { Right axis } \\
30^{\circ}\end{array}$ & $\begin{array}{c}\text { Primum ASD } \\
\text { Common ventricle }\end{array}$ & - & $\begin{array}{l}\text { Pregnancy } \\
\text { termination } \\
\text { and autopsy }\end{array}$ \\
\hline Case 17 & 22 & Solitus & Mesoposition & $0^{\circ}$ & - & Pleural effusion & $\begin{array}{c}\text { Alive, } \\
\text { Following-up }\end{array}$ \\
\hline Case 18 & 33 & Solitus & Dextroposition & $\begin{array}{l}\text { Left axis } \\
45^{\circ}\end{array}$ & - & $\begin{array}{c}\text { Diaphragmatic } \\
\text { hernia }\end{array}$ & $\begin{array}{c}\text { Repair of } \\
\text { diaphragmati } \\
\text { c hernia and } \\
\text { alive }\end{array}$ \\
\hline Case 19 & 24 & Solitus & $\begin{array}{c}\text { Extreme } \\
\text { Levoposition }\end{array}$ & $\begin{array}{l}\text { Left axis } \\
30^{\circ}\end{array}$ & - & $\begin{array}{l}\text { Cystic } \\
\text { adenomatoid } \\
\text { malformation }\end{array}$ & $\begin{array}{l}\text { Pregnancy } \\
\text { termination } \\
\text { and autopsy }\end{array}$ \\
\hline Case 20 & 20 & Solitus & Mesoposition & $0^{\circ}$ & - & Pleural effusion & $\begin{array}{c}\text { Alive } \\
\text { Following-up }\end{array}$ \\
\hline
\end{tabular}


echocardiography after a preliminary diagnosis of dextrocardia on routine ultrasound examination. In present study, only seven of 20 cases were referred for fetal echocardiography after diagnosis of cardiac malposition on routine obstetric ultrasound, and the cases whose preliminary diagnosis of dextrocardia on obstetric ultrasound and magnetic resonance imaging had normal cardiac anatomy and position on pre-postnatal echocardiogram. These studies have shown that fetal cardiac malpositions are difficult to diagnose on routine obstetric ultrasound.

Fetal cardiac malposition is caused by either intrinsic congenital heart diseases or extracardiac malformations. Generally, intrinsic congenital heart diseases cause abnormal cardiac axis $(17,18)$. In addition, extracardiac malformations are often responsible for the abnormal location of the heart in the thorax due to mediastinal shift (19). In our study among 20 cases with cardiac malposition, 16 had congenital heart disease, and four had extracardiac malformation.

Most of the cases with congenital heart disease had abnormal cardiac axis. Shipp et al. (20) reported that $44 \%$ of fetal heart defects were associated with left-sided heart greater than 57 degrees. Smith et al. (17) also reported that left-sided heart greater than 75 degrees correlated with a positive predictive value of $76 \%$ for a heart defect in fetuses. In most of our cases with levocardia and dextrocardia, cardiac axis was greater than 57 degrees (Table 1).

Of six cases with situs ambiguous, five had left atrial isomerism and one right atrial isomerism. This study demonstrated significant predominance of fetuses diagnosed with left atrial isomerism. Some studies have noted that fetuses with left atrial isomerism appear to be more common in utero because of an increased rate of very early death of fetuses with right atrial isomerism (15). All cases with situs ambiguous had severe complex congenital heart disease. It was stated that the cardiac anomalies in right atrial isomerism tend to be more severe than those in left atrial isomerism (18). This study also indicated that the prognosis of cases with left atrial isomerism was better than case with right atrial isomerism.

Of four cases with cardiac malposition due to extracardiac anomalies, one had congenital diaphragmatic hernia and other had cystic adenomatoid malformation. Although previous studies were reported that these anomalies could be associated with cardiac defects and other anomalies, our cases had normal cardiac anatomy $(18,21,22)$.

\section{Conclusion}

The fetal right/left side and axis must be determined correctly for the accurate diagnosis of cardiac malpositions. Therefore, we recommend that Cordes technique provides a simple and reliable determination of the fetal right/left side and fetal situs.

Conflict of interest: None declared.

\section{References}

1. Bronshtein $M$, Gover A, Zimmer EZ. Sonographic definition of the fetal situs. Obstet Gynecol 2002; 99: 1129-30.

2. Cordes TM, O'Leary PW, Seward JB, Hagler DJ. Distinguishing right from left: a standardized technique for fetal echocardiography. J Am Soc Echocardiogr 1994; 7: 47-53.

3. DeVore $\mathrm{G}$. The prenatal diagnosis of congenital heart disease; a practical approach for the fetal sonoggrapher. J Clin Ultrasound 1985; 13: 229- 45.

4. Silverman NH, Golbus M. Echocardiographic techniques for assessing normal and abnormal fetal cardiac anatomy. J Am Coll Cardiol 1985; 5: 20-9.

5. Cyr DR, Guntheroth WG, Mack LA, Shuman WP. A systematic approach to fetal echocardiography using real-time/two-dimensional sonography. J Ultrasound Med 1986; 5: 343-50.

6. Reed K. Fetal echocardiography. Semin Ultrasound CT MR 1991; 12: 2-10.

7. Drose JA. Scanning: Indication and Technique. In: Drose JA, editor. Fetal Echocardiography. Philadelphia: W.B. Saunders Company; 1998. p.15-59.

8. Hagler DJ, O'Leary PW. Cardiac malpositions and abnormalities of atrial and visceral situs. In: Allen HD, Gutgesell HP, Clark EB, Driscoll DJ (eds): Moss and Adams. Heart Disease in Infants, Children and Adolescents Including the Fetus and Young Adult, 6th ed. Philadelphia:Williams and Wilkins; 2001. p. 1151-64.

9. Rabih Chaoui. Cardiac malpositions and syndromes with right or left atrial isomerism. In: Yagel S, Silverman NH, Gembruch U, Cohen SM, editors. Fetal Cardiology. London and NewYork: Martin Dunitz; 2003. p 173-82.

10. Allan LD, Crawford DC, Anderson RH, Tynan M. Spectrum of congenital heart disease detected echocardiographically in prenatal life. Br Heart J 1985; 54:523-6.

11. Özkutlu S, Elshershari H, Akçören Z, Önderoğlu LS, Tekinalp G. Visceroatrial situs solitus with atrioventricular alignment discordance double outlet right ventricle and superoinferior ventricles: fetal and neonatal echocardiographic findings. J Am Soc Echocardiogr 2002; 15: 749-52.

12. Özkutlu S, Ayabakan C, Karagöz T, Önderoğlu L, Deren O, Çağlar M, et al. Prenatal echocardiographic diagnosis of congenital heart disease: comparison of past and current results. Turk J Pediatr 2005; 47: 232-8.

13. Allan LD, Sharland GK, Milburn A, Lochart SM, Groves AM, Anderson $\mathrm{RH}$, et al. Prospective diagnosis of 1.006 consecutive cases of congenital heart disease in the fetus. J Am Coll Cardiol 1994; 23: 1452-8.

14. Comstock CH, Smith R, Lee W, Kirk JS. Right fetal cardiac axis: clinical significance and associated findings. Obstet Gynecol 1998; 91: 495-9.

15. Phoon CK, Villegas MD, Ursell PC, Silverman NH. Left atrial isomerism detected in fetal life. Am J Cardiol 1996; 77: 1083-8.

16. Walmsley R, Hishitani T, Sandor GG, Lim K, Duncan W, Tessier F, et al. Diagnosis and outcome of dextrocardia diagnosed in the fetus. Am J Cardiol 2004; 94: 141-3.

17. Smith RS, Comstock CH, Kirk JS, Lee W. Ultrasonographic left cardiac axis deviation: a marker for fetal anomalies. Obstet Gynecol 1995; 85: 187-91.

18. Russ DR, Weingard JP. Cardiac Malposition. In: Drose JA (ed). Fetal Echocardiography. Philadelphia: WB. Saunders Company;1998. p. 59-76.

19. Allan LD, Lockhart S. Intrathoracic cardiac position in the fetus. Ultrasound Obstet Gynecol 1993; 3: 93-6.

20. Shipp TD, Bromley B, Hornberger LK, Nadel A, Benacerraf BR. Levorotation of the fetal cardiac axis: a clue for the presence of congenital heart disease. Obstet Gynecol 1995; 85: 97-102.

21. Cunniff $\mathrm{C}$, Jones $\mathrm{KL}$, Jones $\mathrm{MC}$. Patterns of malformation in children with congenital diaphragmatic defects. J Pediatr 1990; 116: 258-61.

22. Adzick NS, Harrison MR, Glick PL, Golbus MS, Anderson RL, Mahony BS, et al. Fetal cystic adenomatoid malformation: prenatal diagnosis and natural history. J Pediatr Surg 1985; 20: 483-8. 